\title{
Survei Tentang Analisis Sentimen Pada Media Sosial
}

\author{
Putri Agung Permatasari ${ }^{1}$, Linawati ${ }^{2}$, Lie Jasa ${ }^{3}$ \\ [Submission: 05-03-2021, Accepted: 27-05-2021]
}

\begin{abstract}
Social media has now become an important part of everyday life not only for personal needs but can be used in business, as well as many things that can be done. Social media used such as Facebook, Twitter, Youtube, Instagram, Likenid, and Whatsapp. With the existence of social media, the amount of data available is in the form of images, comments in the form of text or emoticons, videos, and so on, so that people are free to have an opinion. With the analysis of the sentiment of opinion that is developing and many on social media, it can produce useful data and information. In sentiment analysis, data classification algorithms are needed including the Naive Bayes Classifier, Support Vector Machine, K-NN, RNN, C4.5, Lexicon Based, LDA Based Topic Modeling, and several other algorithms. This article examines some of the sentiment analysis literature on social media. Currently, the social media that is often used in analysis is Twitter and algorithm users that can increase the level of accuracy are the Naive Bayes Classifier algorithm and the Support Vector Machine. The results of calculating different data classification accuracy can be seen in the test data in the study.
\end{abstract}

Intisari-Media sosial saat ini telah menjadi bagian penting dalam kehidupan sehari-hari tidak hanya untuk kebutuhan pribadi melainkan bisa di gunakan dalam bisnis, serta banyak hal yang bisa dilakukan. Media sosial yang digunakan seperti Facebook, Twitter, Youtube, Instagram, Likenid, dan Whatsapp. Dengan adanya media sosial tersebut banyaknya data yang ada berupa gambar, comment berupa text atau emoticon, video, dan lainnya, sehingga masyarakat bebas beropini. Dengan adanya analisis sentimen opini yang berkembang dan banyak di media sosial tersebut dapat menghasilkan data dan informasi yang bermanfaat. Dalam analisis sentimen diperlukannya algoritma klasifikasi data diantaranya Naive Bayes Classifier, Support Vector Machine, K-NN, RNN, C4.5, Lexicon Based, LDA Based Topic Modeling, dan beberapa algoritma lainnya. Artikel ini menelaah beberapa literature analisis sentimen pada media sosial. Saat ini media sosial yang sering digunakan dalam analisis adalah Twitter dan pengguna algoritma yang dapat meningkatkan tingkat akurasi adalah algoritma Naive Bayes Classifier dan Support Vector Machine. Hasil perhitungan akurasi klasifikasi data berbeda-beda terlihat pada data uji pada penelitian tersebut.

Kata Kunci- Analisis Sentimen, Teks Mining, Naive Bayes Classifier

${ }^{1}$ Mahasiswa ,Magister Teknik Elektro Universitas Udayana Gedung Pascasarjana Universitas Udayana, Jl. PB Sudirman Denpasar-Bali 80234 INDONESIA (tlp:0361-555225; e-mail: agungputri.p@gmail.com.

2,3Dosen,Magister Teknik Elektro Universitas Udayana Gedung Pascasarjana Universitas Udayana, Jl. PB Sudirman Denpasar-Bali 80234INDONESIA (tlp:0361-555225)e-mail: linawati@unud.ac.id ; liejasa@unud.ac.id

Dinamisnya perkembangan teknologi informasi ke dalam bentuk digital telah merubah gaya hidup manusia. Teknologi Putri Agung Permatasari: Survei Tentang Analisis Sentimen... informasi khususnya internet semakin mudah dikonsumsi dan telah menjadi kebutuhan sebagian besar orang. Menurut Kemenkominfo Republik Indonesia, pengguna internet di Indonesia telah mencapai setidaknya 82 juta pengguna atau lebih dari $1 / 3$ jumlah penduduk Indonesia. Besarnya jumlah pengguna internet di Indonesia menempatkan Indonesia pada peringkat ke-8 dalam hal banyaknya jumlah pengguna dibandingkan negara-negara lainnya [1]. Tujuan pengguna internet di Indonesia sangat beragam mulai dari hanya untuk berinteraksi dan berkomunikasi dengan kerabat melalui media sosial hingga meningkatkan produktivitas kerja.

Media sosial yang sering digunakan masyarakat baik untuk produktivitas kerja ataupun mendukung bisnisnya yaitu Facebook, Twitter, Youtube, Instagram, Linkedin, Twitter, dan Whatsapp.Media sosial tersebut memiliki beberapa kemudahan untuk pengguna seperti fitur yang memungkinkan pengguna berkomentar atau menanggapi unggahan pemilik akun media sosial. Dengan media sosial pengguna bisa mengungkapkan ekspresi ataupun opininya, baik itu berupa ungkapan positif, negatif, dan netral. Tentu hal ini akan berpengaruh terhadap entitas yang diberikan opini atau komentar. Banyaknya unggahan yang ada di media sosial butuh adanya analisis sentimen, yang berfungsi untuk mengklasifikasi data yang terstruktur maupun yang tidak terstruktur.

Saat ini banyak penelitian yang berkaitan tentang analisis sentimen. Analisis sentimen pada media sosial dapat memberikan informasi yang bermanfaat bagi entitas yang diberikan opini. Analisis sentimen dapat mengkalsifikasikan kalimat opini berupa kalimat positif, negatif, dan netral. Sehingga dapat menghasilkan sebuah informasi bagi entitas baik itu perusahaan maupun instansi. Untuk mendukung analisis sentimen tersebut ada berbagai metode yang digunakan diantaranya Naive Bayes Classifier, Support Vector Machine, $K-N N$, RNN, C4.5, Lexicon Based, LDA Based Topic Modeling, dan beberapa algoritma lainnya.

Beberapa literatur yang ada mengenai analisis sentimen khususnya terkait media sosial menjelaskan bahwa metode Naïve Bayes Classifier merupakan metode sederhana yang mempunyai tingkat akurasi dari hasil klasifikasi yang tinggi dimana tingkat akurasinya dipengaruhi oleh banyaknya data uji [2]. Nä̈ve Bayes Classifier dapat dilakukan di perusahaan atau instansi yang sangat dipengaruhi oleh ekspresi ataupun opini masyarakat yang dituangkan dalam fitur media sosial seperti kolom comment.

Artikel ini mencoba menelaah literatur yang membahas tentang analisis sentimen pada media sosial. Hasil dari telaah ini diharapkan dapat membantu peneliti dan pengembang untuk mengetahui perkembangan dan tingkat akurasi klasifikasi pada beberapa algoritma yang digunakan dalam beberapa media sosial sehingga dapat mendapatkan nilai akurasi yang tinggi dan informasi yang tepat.

p-ISSN:1693 - 2951; e-ISSN: 2503-2372 
Sistematika penyajian artikel ini adalah sebagai berikut: Bagian 2 memberikan informasi media sosial dan karakteristik. Bagian 3 menjelaskan meengenai metode dan bahan yang digambarkan melalui skematik penelitan. Bagian 4 memberikan tinjauan singkat tentang analisis sentiment beserta metode klasifikasi. Bagian 5 membahas tentang penelitian terkait penggunakan metode Nä̈ve Bayes Classifier dan garis rencanaa penelitan kedepan.

\section{MEDIA SOSIAL DAN KARAKTERISTIK}

Media sosial merupakanmedia digital yang paling sering digunakan oleh masyarakat saat ini sebagai alat komunikasi jarak jauh dan dua arah [3]. Kumpulan sistem informasi dan aplikasi teknologi berbasis internet yang ada pada media sosial memungkinkan seseorang berbagi informasi dengan komunitas virtualnya. Salah satu media sosial yang terkenal adalah Twitter dan Instagram. Twitter termasuk dalam kelompok microblogging berbasis teks. Twitter sendiritelah berdiri lebih dari 10 tahun. Secara global, pengguna media sosial di tahun 2020 sudah mencapai 160 juta pengguna aktif [4]. Sedangkan Instagram termasuk dalam kelompok media sharing atau media berbagi berbasis visual seperti foto dan video. Twitter dan Instagram memiliki pengguna yang sangat besar di Indonesia.

Zimmerman dan $\mathrm{Ng}$ (2017) menjelaskan beberapa kelompok media sosial sebagai media pemasaran [5] :

1) Social content-sharing service.

- Webblog / blog, merupakan sebuah situs yang memiliki sistem informasi pengelolaan konten sehingga memudahkan penggunanya mengunggah (update dan change)konten secara digital. Blog dilengkapi berbagai fitur sehingga menjadikannya berfungsi sebagai media sosial seperti comment, tag, link, subscription dan sebagainya. Umumnya blog digunakan untuk menulis jurnal keseharian penulisnya ataupun tips ataupun berita yang terkait dengan industri dari pemilik blog. Contoh dari blog adalah Wordpress, Blogger, Medium dan Tumblr.

- Media (Video dan Photo) Sharing, merupakan jenis media sosial yang mendapatkan banyak perhatian pengguna saat ini. Hal ini disebabkan karakter pengguna kaum milenial yang sangat visual. Sehingga platform berbagi media visual mengalami trend yang sangat positif dalam beberapa tahun terakhir. Media yang bisa dibagikan sangat beragam dari suara, gambar dan video.

2) Social-bookmarking services, merupakan kelompokmedia sosial yang sudah cukup lama ada. Media sosial ini memiliki fitur untuk vote/recommend dan bookmark unggahan yang ada di media sosial tersebut sehingga pengguna lainnya dapat melihat daftar situs yang kita dan pengguna lain rekomendasikan. Contoh media sosial ini adalah StumbleUpon, Delicious, dan sebagainya.

3) Social news services, merupakan salah satu kelompok media sosial yang fokus merekomendasikan daftar artikel (recommended list) dari situs berita, blog ataupun website. Pengguna lainnya dapat melakukan voting terhadap daftar artikel tersebut sehingga artikel-artikel dalam daftar memiliki masing-masing nilai atau peringkat. Contoh media sosial ini adalah Dig, Reddit dan lain-lain.

4) Social geolocation and meeting services, merupakan kelompok media sosial yang membagikan informasi ruang sesungguhnya (real-space) alih-alih ruang cyber. Media sosial ini memanfaatkan Global Positioning System (GPS). Contoh media sosial ini adalah Foursquare dan Meetup.

5) Social-networking services, merupakan salah satu kelompok sosial yang paling banyak digemari saat ini. Socialnetworking memiliki berbagi dan bertukar informasi personal seperti foto, video, pesan dan audio kepada pengguna lainnya.Dari sudut pandang bisnis, media sosial ini memiliki berbagai fitur yang memungkinkan penggunanya melakukan kegiatan pemasaran tertarget. Hal ini dimungkinkan dengan adanya business account dan platform beriklan serta big data yang dimiliki media sosial tersebut sehingga dapat mengklasifikasikan datanya sesuai kebutuhan perusahaan pengiklan.

- Full networks, contohnya Facebook dan Google+.

- Short message network, contohnya Twitter

- Professional network, contonya Linkedin

- Speciality network, contohnya Quora

6) Community-building services, merupakan contoh media sosial yang bertujuan untuk membangun komunitas. Media sosial ini merupakan salah satu tipe yang sudah lama. Contohnya adalah TripAdvisor, Yelp, Wikipedia dan sebagainya.

\section{BAHAN DAN METODE}

Penelitian ini melakukan tinjauan terhadap analisis sentimen pada media sosial. Khusus nya penelitian yang dilakukan dengan banyak nya data atau text. Data yang digunakan berasal dari artikel jurnal, publikasi conference, dan dokumen lainnya. Data ini diperoleh menlalui mengindeks atau mesin pencari seperti Google Scholar, ResearchGate, IEEE Xplore, dan Jurnal Unud MITE ( Majalah Ilmiah Teknologi Elektro ). Skematik penelitian yang dilakukan ditunjukkan pada gambar 1 .

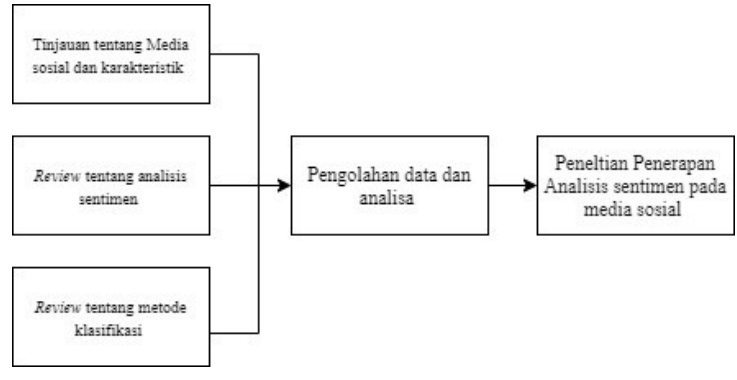

Gambar 1: Skematik Penelitian 
Penelitian dilakukan melalui beberapa tahapan. Tahapan pertama melakukan tinjauan tentang media sosial dan karakteristik, review tentang analisis sentimen, dan review tentang metode klasifikasi. Selanjutnya pada tahapan kedua dilakukan pengolahan data dan analisa dari hasil telaah literature.

\section{ANALISIS SENTIMEN}

Analisis sentimen adalah proses untuk memahami dan mengelompokan suatu kata yang dibagi menjadi beberapa kelas. Analisis sentimen juga disebut opinion mining yang dapat diartikan menggali opini dan emosi dari data uji. Tujuan dari analisis sentimen itu sendiri adalah untuk mengekstrak atribut dan komponen dari beberapa komentar yang ada di media sosial dan sehingga dapat menentukan beberapa kelas positif, negatif dan netral [6].

Dalam text mining dapat digunakan beberapa teknik pembelajaran. Diantara beberapa metode pembelajaran, Naive Bayes Classifier dinilai sebagai metode yang memiliki kemampuan yang baik dalam melakukan klasifikasi data dibandingkan metode klasifikasi lainnya terutama dalam hal akurasi. Metode ini dapat digunakan untuk menganalisis data berbasis teks yang sangat besar. Analisis sentimen juga dapat melibatkan pembelajaran bahasa dengan menggunakan Part of Speech (POS) Tagging. Metode inimemberikan label (tag) kata-kata pada sebuah kalimat. Berikut gambar pengelompokan klasifikasi data dari sistem analisis sentimen. Sistem analisis sentimen ditunjukkan pada gambar 2 .
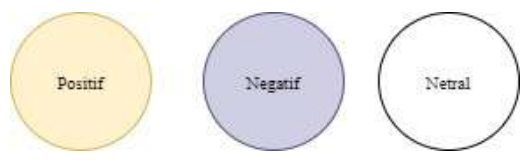

Gambar 2: Sistem Analisis Sentimen

\section{A. Support Vektor Machines (SVM)}

SupportVector Machines (SVM) merupakan salah satu metode pembelajaran tersupervisi yang dapat menganalisis data dan mengenali pola. SVM umumnya digunakan untuk melakukan klasifikasi serta regresi. Selain itu, SVM dapat melakukan prediksi dan penilaian pada sebuah sistem. Para peneliti SVM menggunakannya sebagai pengelompokan dasar dalam menentukan superioritas classifier yang diusulkan [5]. SVM akan menilai volume kemunculan kata atau mengklasifikasikan polaritas dari opini atau pernyataan .

Teknik SVMakan mengelompokkan data dalam dua bagian atau lebih. Selanjutnya data yang telah dikelompokkan akan dipisahkan dengan garis dimana garis ini disebut hyperplane. Keberadaan SVM ditujukan untuk optimasi garis tersebut.

Jika diketahui training vector sebagai berikut

$X_{i} \in R^{\Phi}, 1, \ldots, n$ dalam dua kelas, dan vector $y \in\{1 .-1]^{n}$, metode $S V M$ menyelesaikan permasalahan berikut :

$$
\min _{\varnothing} \frac{1}{2} \alpha^{T} Q \alpha-e^{T}
$$

Subject to

$$
y_{i}\left(w^{T} \emptyset\left(x_{i}\right)+b\right) \geq 1-C_{i,} C_{i} \geq 0, i=1_{s, n} n
$$

Putri Agung Permatasari: Survei Tentang Analisis Sentimen...
Dengan elemen keduanya :

$$
\min _{w_{w} b_{x} c} \frac{1}{2} w^{t} w+c \sum_{i=1}^{n} c_{1}
$$

Subject to

Dimana e $0 \leq \alpha \leq \mathcal{C}_{x} i=1_{\alpha_{\alpha} n} n$ adalah vector dari keseluruhan, $\mathrm{C}>0$ adalah batas atas, $\varphi$ adalah $\mathrm{n}$ dari $\mathrm{n}$ positif semidefinite matrix .

\section{B. Naive Bayes Classifier (NBC)}

Naive Bayes Classifier merupakan teknik pembelajaran algoritma data mining. Teknik yang digunakan didasarkan pada metode probabilitas dan statistik. Dalam klasifikasi Naive Bayes terdapat dua proses penting yaitu learning (training) dan testing [7]. Naive Bayes Classifier dapat digunakan untuk mengklasifikasi sebuah opini positif maupun negatif. Hasil dari penelitian-penelitian yang ada menunjukkan efektivitas metode Naive Bayes Classifier sebagai salah satu metode yang paling baik untuk pelatihan. Selain itu hasil klasifikasinya juga memiliki tingkat akurasi yang baik [8]. Proses algoritma klasifikasi Naive Bayes meliputi:

1) Input data, yang dimaksud dengan data disini yaitu data dari sumber yang ditentukan sebelumnyayang berisi data berbasis tekstual dimana umumnya berupa opini masyarakat.

2) Data prepocessing, yangmerupakan tahapan awal pengolahan data berbasis tekstual dalam analisis sentimen. Di tahapan ini, digunakan beberapa metode yaitu :

- parsing atau tokenizer untuk memisahkan data tekstual menjadi beberapa token,

- cleansing adalah proses selanjutnya yaitu menghilangkan kata yang tidak relevan,

- normalization merupakan tahapan untuk normalisasi kalimat atau teks,

- case folding merupakan tahapan merubah bentuk dasar kata menjadi kata-kata yang berkarakter dan seragam.

\section{K-Nearest Neighbor $(K-N N)$}

$K$-Nearest Neighbor $(K-N N)$ merupaka nsalah satu metode yang digunakan untuk melakukan klasifikasi terhadap objek data pembelajaran yang memiliki jarakterdekat dengan objek tersebut. K-NN adalah algoritma yang menghitung kemiripan pada tiap data uji dan semua data awal untuk menghitung daftar nearest neighbor-nya [9]. $K-N N$ bertujuan untuk mengklasifikasikan objek berdasarkan atribut dan data training. Data klasifikasi tidak menggunakan data untuk dicocokan dan hanya berdasarkan memori. Di dalam query terdapat titik yang akan ditemukan sejumlah $\mathrm{k}$ titik training yang posisinya paling dekat dengan titik query. Klasifikasi ketetanggaan sebagai nilai prediksi dari sample uji yang baru.

\section{TEKNIK DAN PROSES KLASIFIKASI}

p-ISSN:1693 - 2951; e-ISSN: 2503-2372 
Analisis sentimen dalam proses nya memnggunakan metode klasifikasi untuk menetukan tingkat akurasi serta algoritma yang digunakan. Berikut beberapa teknik dan proses klasifikasi beberapa algoritma yang dapat di telaah dalam review artikel analisis sentimen pada media sosial.

\section{A. Proses Klasifikasi Nä̈ve Bayes Classifier}

Klasifikasi Naive Bayes terhadap dokumen tekstual yaitu menampilkan setiap dokumen tekstual dengan atribut yang bermakna demikian sehingga $X 1, X 2, X 3, \ldots, X n$ " memiliki makna dimana $X 1$ untuk kata pertama, $X 2$ adalah kata kedua, dan sebagainya. Kemudian Naïve Bayes Classifier akan mencari nilai probabilitas tertinggi dari [10]:

$V M A P=\operatorname{VjeV} \operatorname{argmax} P(x 1, x 2, x 3, \ldots, x n \mid V j) P(V j)$

$P(x 1, x 2, x 3, \ldots, x n)$

Jika nilai dari $\mathrm{P}(X 1, \ldots, X n)$ adalah konstan untuk semua kategori $V j$ maka dari persamaan (1) dapat ditulis :

$$
V_{M A P}=\frac{\operatorname{argmax}}{V j e V} \quad P\left(X_{1}, X_{2}, X_{3}, \ldots . ., X_{n} \mid \mathrm{Vj}\right) \mathrm{P}(\mathrm{Vj})
$$

Sehingga dari persamaan (2) dapat ditulis sebagai :

$$
V_{M A P}=\frac{\operatorname{argmax}}{V j e V} p_{i=1}^{n} \mathrm{P}(\mathrm{Xi} \mid \mathrm{Vj}) \mathrm{P}(\mathrm{Vj})
$$

Keterangan :

$$
\begin{array}{ll}
V_{M A P} \quad: \text { semua kategori yang diujikan } \\
\mathrm{Vj} & : \text { kategori tweet, dengan : } \\
\hline J_{1} & : \text { sentimen positif } \\
\mathrm{I}_{2} & : \text { sentimen negatif } \\
V_{3} & : \text { sentimen netral } \\
\mathrm{P}(X i \mid V j) & : \text { probabilitias } X i \text { pada kategori } \\
\mathrm{P}(\mathrm{Vj}) & : \text { probabilitas dari } V j
\end{array}
$$

Pada saat pelatihan untuk $\mathrm{P}(X i \mid V j)$ menggunakan rumus Chi Square yaitu :

Dan nilai $\mathrm{P}(V j)$ dapat dihitung menggunakan persamaan berikut (1) :

$P\left(V_{j}\right)=\frac{\mid \text { docs } \mathrm{j} \mid}{\mid \text { contoh } \mid}$

Keterangan:

$|\operatorname{docs} \mathrm{j}|=$ jumlah dokumen setiap kategori |contoh $\mid=$ jumlah dokumen dari semua kategori $P\left(X_{i} \mid V_{j}\right)=\frac{\left(N_{00}+N_{11}+N_{10}+N_{01}\right)\left(N_{00} N_{11}+N_{10} N_{01}\right)^{2}}{\left(N_{11}+N_{01}\right)\left(N_{11}+N_{10}\right)\left(N_{10}+N_{00}\right)\left(N_{01}+N_{00}\right)}$

\section{B. Text Mining}

Text mining atau dikenal juga text analysis merupakan algoritma untuk mencari informasi dari data tekstual yang terstruktur. Text mining dapat membantu peneliti dalam memahami maksud dari sebuah pernyataan (data tekstual) tanpa harus membaca semua pernyataan tersebut. Pengelolaan data pada text mining terbagi dalam beberapa tahap. Tahapan ini dikenal dengan Text Preprocessingyang terdiri dari [11]:
- Transform Cases
- Filter Stopword
- Filter Tokenize
- Stemming

\section{Proses Klasifikasi K-Nearest Neighbor}

K-NN menghitung jarak atau kemiripan. Berikut adalah algoritma K-NN [12]:

1. $k$ adalah jumlah nearest neighbor dan $D$ adalah kumpulan awal

2. Untuksetiap data awal $\mathrm{z}=(x, y)$

3. Menghitung $d(x, x)$ jarak antara $\mathrm{z}$ dengan tiap data $(\mathrm{x}, \mathrm{y}) \in \mathrm{D}$

4. Pilih $D z \subseteq D$, sejumlah $k$ data dengan jarak terdekat dengan $\mathrm{Z}$

5. Menghitung jarak Euclidean antara data barudengan jarak semua data training. Terlampir cara perhitungan Euclidean distance adalah dengan persamaan sebagai berikut :

$$
\mathrm{D}(\mathrm{X}, \mathrm{Y})=\sqrt{\sum_{k=1}^{\mathrm{n}}(\mathrm{Xk}-\mathrm{Yk})^{2}}
$$

(1)

Keterangan :

$\mathrm{D}=$ Jarak Antara dua titik $\mathrm{x}$ dan $\mathrm{y}$

$\mathrm{X}=$ Data $\mathrm{Uji}$

$\mathrm{Y}=$ Sample

$\mathrm{N}=$ Dimensi data

6. Kemudian urutkan hasilnya berdasarkan jarak $\mathrm{K}$ yang ditentukan jika $\mathrm{K}=3$ artinya dipilih 3 jarak terkecil dari hasil tersebut.

7. Selanjutnya menggunakan mayoritas atribut kelas pada 3 tentangga terdekat yang sudah dipilih untuk menentukan prediksi kelas pada data baru tersebut. Misalkan pada 3 tetangga terdekat memiliki 2 atribut kelas positif dan 1 atribut kelas negative maka kelas pada data baru tersebut adalah positif.

\section{PEMBAHASAN}

Berdasarkan dari telaah yang telah dilakukan terdapat 21 buah dokumen yang membahas tentang analisis sentimen. Lebih detail dari setiap paper akan dijelaskan dibawah ini.

\section{A. Penerapan Analisis Sentimen}

Penelitian [13] terkait analisis sentimen yang bertujuan untuk mengetahui persepsi masyarakat terkait kenaikan harga jual rokok melalui media sosial. Media sosial yang digunakan yaitu Twitter dengan metode klasifikasi Naïve Bayes Classifier dan Lexion Based. Dengan jumlah data latih yang sama sebanyak 350 buah dari opini masyarakat di Twitter, metode klasifikasi Nä̈ve Bayes Classifier dapat memberikan nilai presentase precision, recall, dan accuracy yang lebih tinggi daripada metode Lexion Based. Namun dari hasil ketepatan pada metode klasifikasi Naïve Bayes Classifier sangat tergantung dengan jumlah data latih yang digunakan, dan mendapatkan nilai akurasi sebesar $80 \%$.

Penelitian [14] membahas tentang deteksi kemacetan di Jakarta. Dalam penelitian ini dinyatakan bahwa besarnya volume kendaraan serta sedikitnya ketersediaan fasilitas kendaraan umum menjadi salah satu penyebab kemacetan di Jakarta. Dengan adanya keluhan kemacetan tersebut sering kali pengguna jalan posting keluhan mereka di Twitter yang biasa disebut tweets. Setiap tweets dapat disimpan dan dapat diunduh untuk dianalisa. Aplikasi yang dirancang terhubung dengan Hadoop, Flume, Hive, dan Twitter API untuk melakukan streaming data Twitter secara real-time. Aplikasi ini dilengkapi berbagai fitur diantaranya fitur pertama untuk melihat isi data, fitur kedua untuk pencarian data tabel tweet pada tabel dan fitur 
DOI: https://doi.org/10.24843/MITE.2021.v20i02.P01

ketiga untuk menampilkan hasil analisa berdasarkan data pada tabel. Penelitian yang dilakukan mendapatkan nilai akurasi sebesar $80 \%$.

Penelitian [15] yang membahas tentang konten media sosial Instagram yang dikelola oleh e-Commerce Shopee Indonesia dengan memanfaatkan analisis sentimen dan LDA-Based Topic Modeling. Dalam melakukan bisnis pada era digital memahami konsumen merupakan salah satu cara perusahaan untuk dapat terus melihat feedback yang diberikan konsumen terhadap produk maupun jasa yang diberikan perusahaan. Metode yang digunakan adalah menggunakan Nä̈ve Bayes Model, serta pembuatan Topic Modeling dengan menggunakan LDA-Based Topic Modeling. Sentimen yang terbentuk dalam konten komentar Instagram Shopee dan Flashsale 11:11 adalah negatif. Data yang dilakukan dibedakan menjadi dua yaitu data pengujian 30\% dan data pelatihan 70\%. Sehingga dalam proses pengkalsifikasian Naive Bayes Classifier memiliki tingkat akurasi sebesar 88,73\%.

Penelitian [16] membahas tentang kicauan (tweets) masyarakat di media sosial Twitter tentang opini terhadap pemerintahan Presiden Joko Widodo. Banyak opini berupa pujian dan kritikan. Dengan menggali informasi tersebut serta melakukan klasifikasi text data yang diperlukan untuk analisis sentimen dengan menggunakan metode Nä̈ve Bayes Classifier. Penelitian ini membantu menganalisis opini masyarakat tersebut. Hasil dari penelitan ini bahwa klasifikasi pada data uji memberikan nilai akurasi sebesar 97\%, nilai akurasi untuk sentimen negatif sebesar $96 \%$ serta positif sebesar $98 \%$.

Penelitan [17] membahas analisis sentimen yang dapat dilakukan dengan menggunakan berbagai macam data mulai dari dokumen ataupun opini dari media sosial. Dalam penelitian ini menggunakan media sosial Facebook. Penelitian ini menggunakan POS Tagging sebelum dilakukan klasifikasi teks. POS Tagging yaitu proses pelebelan kata yang bertujuan untuk menentukan apakah termasuk opini atau non opini. Pelebelan kata ini menggunakan Rule Based dan Hidden Markov Model. Sedangkan analisis sentimen yang dilakukan dalam penelitian ini menggunakan algoritma Naïve Bayes Classifier. Hasil penelitian yang dilakukan menunjukkan nilai akurasi yaitu $87,1 \%$.

Penelitian [18] membahas tentang memantau komentar masyarakat terhadap produk secara real time. Serta membahas efek metode sebelum pemprosesan teks kinerja klasifikasi sentimen dalam dua jenis tugas klasifikasi dan menyimpulkan kinerja klasifikasi tersebut. Pengukuran dari pengklasifikasi sentimen Twitter di tingkatkan sebelum pemprosesan metode yang dilakukan yaitu memperluas dan mengganti negasi. Pengklasifikasi Naive Bayes dan Random Forest lebih sensitif daripada metode yang lain. Dari pembahasan diatas penelitian ini mempelajari metode pemrosesan yang berbeda sehingga mempengaruhi klasifikasi sentimen di Twitter. Hasil dari penelitian tersebut menunjukkan dengan menggunakan algoritma Naive Bayes Classifier menghasilkan tingkat klasifikasi akurasi sebesar 68,5\%, sedangkan dengan menggunakan algoritma $S V M$ nilai akurasi yang dihasilkan sebesar $79 \%$.

Penelitian [19] membahas tentang evaluasi opini tentang topik terkait layanan nirkabel dengan menerapkan pemrosesan bahasa alami (NLP) ke geo-tag data Twitter. Metode dekteksi Putri Agung Permatasari: Survei Tentang Analisis Sentimen... sentimen umum saat ini bukanlah topik spesifik. Dalam penelitian ini mengembangkan kerangka kerja sentimen khusus topik layanan nirkabel baru yang menghasilkan lebih tinggi akurasi daripada kerangka kerja NLP umum. Langkah pertama memberi sentimen baru yang disebut dengan Signal Senti Word $(S S W)$ dan membandingkan kinerja dengan dua pustaka lainnya. Metode yang diterapkan dalam penelitian ini terdapat tiga metode pembelajaran mesin yaitu Naive Bayes, SVM dan Recurent Neural Network (RNN) untuk membangun analisis sentimen. Hasil dari penelitian ini menunnjukkan SSW memiliki keunggulan dala akurasi dan keahlian klasifikasi sentimen. Serta hasil dari metode pembelajaran mesin dan menilai kemampuan menunjukkan bahwa Naive Bayes dan SVM telah memperoleh manfaat yang dramatis dari pemfilteran SSW dan Naive Bayes dapat mencapai skor tertinggi $72 \%$. Namun, $R N N$ mungkin masih memiliki potensi untuk Twitter analisis sentimen dan rencana untuk melakukan pekerjaan lebih lanjut .

Penelitian [20] membahas tentang memprediksi kepreibadian proaktif. Denggan 901 perserta dipilih dengan metode cluster sampling, teks pertanyaan jawaban singkat ditargetkan dan sosial peserta teks postingan media ( Weibo ) diperoleh sementara laberl kepribadian proaktif perserta dievaluasi oleh para ahli. Untuk membuat kelasifikasi terdapat lima algortima pembelajaran mesin disertaka Support Vector Mesin (VSM), XGBoost, K-Nearst-Neighbours (KNN), Naive Bayes (NB) dan Regresi Logistik (LR). Tujuh indikator berbeda yang meliputi Sensitivitas (SEN), Kekhususan (SPE), Nilai Prediktif Positif (PPV), Nilai Prediktif Negatif (NPV) dan area bawah Kurva (AUC), dikombinasikan dengan validasi silang hierakis juga digunakan untuk membuat komprehensif evaluasi model. Hasil dari penelitan ini teknologi penambangan teks menunjukkan nilai yang luar biasa dalam memprediksi kepribadian proaktif individu, khususnya untuk mengidentifikasi individu dengan kepribadian proaktif rendah. Akurasi dan spesifisitas terbaik masing-masing mencapai $84,2 \%$ dan $96,9 \%$.

Penelitian [21] membahas tentang pertumbuhan eksponensial permintaan organisasi bisnis dan pemerintah mendorong peneliti untuk menyelesaikan penelitian dalam sentimen analisis. Penelitian ini memanfaatkan empat pengklasifikasi pembelajaran mesin yang baik yaitu Naive Bayes, J48, BFTree dan OneR untuk pengoptimalan analisis sentimen. Penelitian dilakukan dengan menggunakan tiga kumpulan data yang dikompilasi secara manual. Naive Bayes cukup cepat namun OneR lebih menjukkan dalam tingkat akurasi akurasi sebesar 91,3\% . Pemprosesan metodologi yang diusulkan terbatas untuk mengekstrak kata-kata asing, emoticon dan memanjang kata-kata dengan sentimen yang sesuai.

Penelitian [22] ini dilakukan pada aplikasi Ruang Guru di Twitter. Untuk melakukan pengecekan keberhasilan aplikasi adalah dengan analisis sentimen. Pada penelitian ini menggunakan metode pengklasifikasi data menggunakan algoritma Naive Bayes Classifier, Support Vector Machine $(S V M), K$-Nearest Neighbour $(K-N N)$, dan feature selection dengan algoritma Particle Swarm Optimization (PSO). Berdasakan dari hasil penelitian tersebut bahwa pengguna feature selection PSO dapat meningkatkan akurasi p-ISSN:1693 - 2951; e-ISSN: 2503-2372 
pengklasifikasian, sehingga dari pengujian secara keseluruhan algoritma $S V M(P S O)$ mimiliki nilai akurasi yang paling tinggi sebesar 78,55\%, K-NN (PSO) memiliki nilai akurasi sebesar $77,22 \%$, dan untuk $N B C$ (PSO) nilai akurasi adalah $67,32 \%$ dan dapat diartikan klasifikasi yang dilakukan gagal.

Penelitian [23] ini mereview media massa menggunakan metode C4.5. Penelitian ini bertujuan untuk pemantauan dan meningkatkan tingkat kepuasan pada konsumen. Beberapa konsumen meluapkan opini pada media sosial seperti Facebook, Twitter atau situs media lainnya. Hasil dari penelitian ini diperoleh dengan menggunakan metode forward selection dan algoritma C4.5 menghasilkan nilai akurasi sebesar 84,00\% lebih baik dari penelitian sebelumnya yang dinmana menghasilkan nilai akurasi sebesar 80,00\%. Sehingga ada peningkatan nilai akurasi dengan menggunakan algoritma C4.5.

Penelitian [24] ini melakukan analisis sentimen terhadap konten radikal, banyaknya orang yang yang berpaham radikal terhadap orang lain. Penyebaran konten radikal tersebut dilakukan pada media sosial Twitter. Dengan menggunakan metode Support Vector Machine (SVM) diharapkan mengetahui konten radikal positif dan konten radikal negatif. Berdasarkan penelitian tersebut tingkat hasil nilai akurasi yang paling tinggi adalah $70 \%$ dengan menggunakan data latih sebanyak 80 dokumen dan data uji yang dilakukan 20 dokumen.

Penelitian [25] ini melakukan pengambilan opini masyarakat di media sosial Twitter tentang tanggapan pemindahan ibu kota negara Indonesia dengan menggunakan metode klasifikasi Naive Bayes Classifier. Data yang digunakan di Twitter dengan hastag \#IbukotaPalangkaraya dan \#YukUsulIbukotaDimana dari data tersebut adanya tahap PreProcessing. Sehingga hasil dari penelitian tersebut dengan 200 data tweet menghasilkan nilai akurasi rata-rata sebesar $89,86 \%$. Dengan menggunakan data latih dan data uji 50:50, kesimpulan yang diperoleh apabila data latih lebih besar dari data uji maka hasil akurasi yang dihasilkan lebih tinggi.

Penelitian [26] ini melakukan analisis sentimen untuk mengetahui opini masyarakat tentang pelayanan maskapai penerbangan pada media sosial Twitter dengan menggunakan algoritma Support Vector Machine (SVM). Sehingga dapat membantu perusahaan maskapai dalam evaluasi serta membantu masyarakat dalam pemilihan maskapai yang tepat. Hasil dari penelitian ini dengan menggunakan algoritma SVM adalah dengan jumlah iterasi maksimum sebanyak 50 kali dengan menggunakan lexicon based didapatkan akurasi paling baik sebesar $40 \%$, precision sebesar $40 \%$, recall sebesar $100 \%$, dan $f$-measure sebesar $57,14 \%$. Hasil juga dapat dipengaruhi oleh parameter yang optimal dan fitur yang digunakan.

Penelitian [27] ini dilakukan untuk mengetahui oleh-oleh favorit yang berada di Yogyakarta pada media sosial Instagram dan Twitter sehingga dapat di rekomendasikan. Penelitian ini melakukan dua metode yaitu lexicon based dan Support Vector Machine (SVM). Hasil dari penelitian ini dengan menggunakan data uji yang sama yaitu 50. Hasil dari metode lexicon based tingkat akurasi yang diperoleh lebih tinggi daripada metode SVM dengan akurasi sebesar $87,78 \%$ namun hasil dari recall metode SVM lebih baik daripada lexicon based sebesar 100\%.

Penelitian [28] ini bertujuan untuk mengetahui opini masyarakat di media sosial Twitter tentang viral Desa Penari dengan menggunakan metode lexicon based. Proses data dibagi menjadi tiga bagian yaitu positif, negatif, dan netral.
Pengumpulan data menggunakan API search Twitter dengan data tweet yang diambil Desa Penari yaitu 1000 buah komentar. Dengan menghasilkan komentar positif sebanyak 3.3\%, negatif $20 \%$ dan netral sebesar $76,7 \%$.

Penelitian [29] ini tentang opini masyarakat terhadap film pada media sosial berbahasa Indonesia dengan menggunakan metode Naive Bayes Classifier dengan perbaikan tidak baku. Dengan tujuan sebagai mengevaluasi dalam menonton film serta meningkatkan produksi film. Pada pengujian proses preprocessing dilakukan sebanyak 6 tahapan dan perbaikan kata tidak baku dengan penambahan normalisasi dapat memberikan hasil klasifikasi yang lebih baik yaitu sebesar 98,33\% apabila dibandingkan dengan yang hanya dilakukan perbaikan kata baku dengan menggunakan kamus_katabaku menghasilkan nilai akurasi sebesar $91,67 \%$.

Penelitian [30] ini tentang opini masyarakat terhadap pilkada pemilihan wakil rakyat dan diungkapkan melalui media sosial Twitter. Teknik klasifikasi untuk mengetahui opini positif dan negatif dengan menggunakan perbandingan dua metode klasifikasi $S V M$ dan k-means. Hasil dari penelitian ini menyimpulkan bahwa metode algoritma $S V M$ tingkat akurasi yang dihasilkan lebih tinggi 98\% sedangkan dengan menggunakan metode clutering dengan algoritma k-means yaitu $82 \%$.

Penelitian [31] ini bertujuan untuk mengetahui banyaknya opini masyarakat terhadap terhadap Covid -19 yang berkembang dan penyebaran yang sangat tinggi di Indonesia, serta belum adanya obat untuk menyembukan virus tersebut. Adanya opini tersebut masyarakat menuangkan opini dalam media sosial. Untuk mengetahui pengklasifikasi menjadi positif dan negatif penelitian ini menggunakan perbandingan antara algoritma Naive Bayes Classifier dan K-Nearest Neighbor. Hasil dari penelitian tersebut didapatkan nilai akurasi pada algoritma Naive Bayes Classifier sebesar $85 \%$ dan pada algoritma K-Nearest Neighbor sebesar $82 \%$.

Penelitian [32] ini dilakukan untuk mengetahui komentar masyarakat tentang pemilihan calon Gubernur Jawa Timur 2018 pada media sosial Twitter sehingga mendapatkan nilai akurasi paling optimal dan maksimal. Metode klasifikasi yang digunakan dalam penelitian ini adalah Naive Bayes Classifier. Penelitian tersebut menggunakan dua akun yang berbeda yaitu Khofifah dan Guslpul. Dari hasil dataset akurasi yang paling tinggi sebesar $77 \%$ yang dilakukan di Twitter Khofifah.

Penelitian [33] bertujuan untuk mengetahui bagaimana opini masyarakat tentang pengguna aplikasi Gojek di media sosial Twitter. Metode klasifikasi data menggunakan algoritma SVM untuk mendapatkan opini positif, negatif dan netral. Hasil dari pelabelan data secara manual menggunakan metode $S V M$ menghasilkan tingkat akurasi keseluruhan sebesar 79,19\%.

Berdasarkan hasil review sebelumnya menunjukkan bahwa tingkat akurasi klasifikasi penelitian berbeda, dalam pemilihan data dari media sosial dan algoritma yang digunakan.

\section{B. Media Sosial yang digunakan}

Beberapa literatur yang sudah dibahas data yang sering diambil pada media sosial. Sebaran penelitian yang menggunakan data pada media sosial dapat dilihat pada tabel 1 .

TABEL I

SEBARAN MEDIA SOSIAL YANG DILAKUKAN 


\begin{tabular}{|l|l|}
\hline Media Sosial & \multicolumn{1}{|c|}{ Penelitian } \\
\hline Twitter & {$[13],[14],[16],[18],[19],[22],[23],[24],[25],[26],[27]$} \\
& $,[28],[29],[30],[31],[32],[33]$ \\
\hline Facebook & {$[17],[23],[27],[29]$} \\
\hline Instagram & {$[15],[23],[27],[29]$} \\
\hline
\end{tabular}

Berdasarkan hasil mapping dari penggunaan pengambilan data analisis sentiment di media sosial, penggunaan data yang sering dilakukan dalam Analisis Sentimen adalah pada media sosial Twitter, dikarenakan teks yang digunakan dalam media sosial Twitter adalah 140 karakter dalam satu kali tweet. Sehingga dapat memudahkan bagi peneliti untuk mengambil data. Dengan menggunakan API (Application Programming Interface) memberikan kemudahan untuk mengambil data dari Twitter. Proses penyaringan kata dari hasil tweet sampai dataset tidak memakan waktu yang banyak. Jumlah penelitian pengguna pengambilan data pada media sosial ditunjukkan pada gambar 3 .

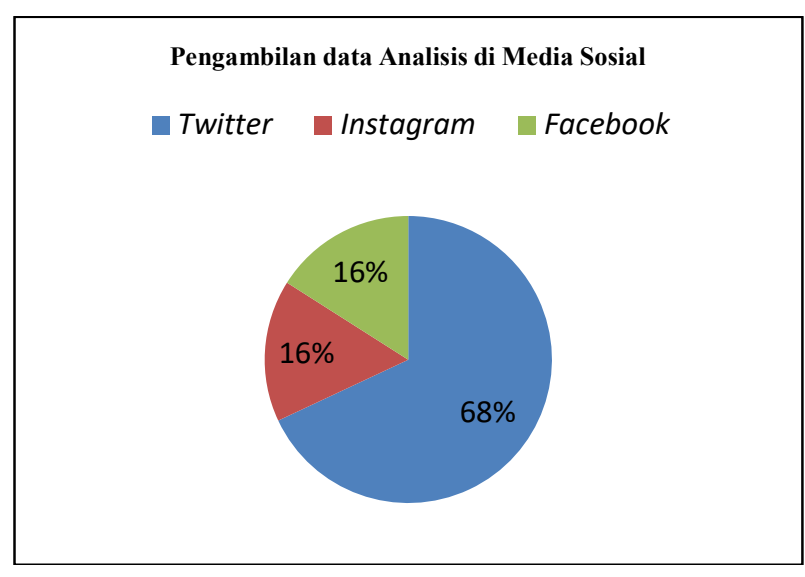

Gambar 2: Pengambilan data Analisis di Media Sosial

Gambar 2 merupakan jumlah pengambilan data di media sosial Twitter, Instagram dan Facebook yang menunjukkan 68\% lebih banyak mengambil data pada media sosial Twitter. Dalam melakukan analisis sentimen tidak hanya dilakukan di Youtube, $W e b$, e-commerce. Pemilihan media sosial dalam penelitian dapat dilakukan sesuai kebutuhan sehingga data yang ada dapat membantu proses analisis sentimen.

\section{Metode Klasifikasi yang digunakan}

Berdasarkan dari hasil telaah literature yang telah dilakukan, maka dapat dilakukan mapping terhadap pemilihan metode dan algoritma klasifikasi data yang digunakan dilihat pada tabel 2.

TABEL 2

ALGORITMA KLASIFIKASI DATA

\begin{tabular}{|c|c|}
\hline $\begin{array}{c}\text { Algoritma } \\
\text { Klasifikasi } \\
\text { Data }\end{array}$ & Penelitian \\
\hline Naive Bayes & {$[13],[14],[15],[16],[17],[18],[19],[20],[21],[22$} \\
Classifier & ]$,[25],[29],[31]$ \\
\hline $\begin{array}{c}\text { Support Vector } \\
\text { Machine (SVM) }\end{array}$ & {$[18],[19],[20],[22],[24],[26],[27],[30],[33]$} \\
\hline Recurrent & {$[19]$} \\
Neural Network & \\
\hline
\end{tabular}

Putri Agung Permatasari: Survei Tentang Analisis Sentimen...

\begin{tabular}{|c|c|}
\hline $\begin{array}{c}\text { LDA Based } \\
\text { Topic Modeling }\end{array}$ & {$[15]$} \\
\hline Lexicon Based & {$[13],[26],[28]$} \\
\hline C4.5 & {$[23]$} \\
\hline K-Nearest & {$[20],[22],[30],[31]$} \\
Neighbor & \\
$($ KNN) & \\
\hline
\end{tabular}

Tabel 2 merupakan hasil mapping terhadap pemilihan metode dan algoritma klasifikasi data dalam analisis senitimen. Jumlah pemilihan algoritma terlihat pada gambar 3 .

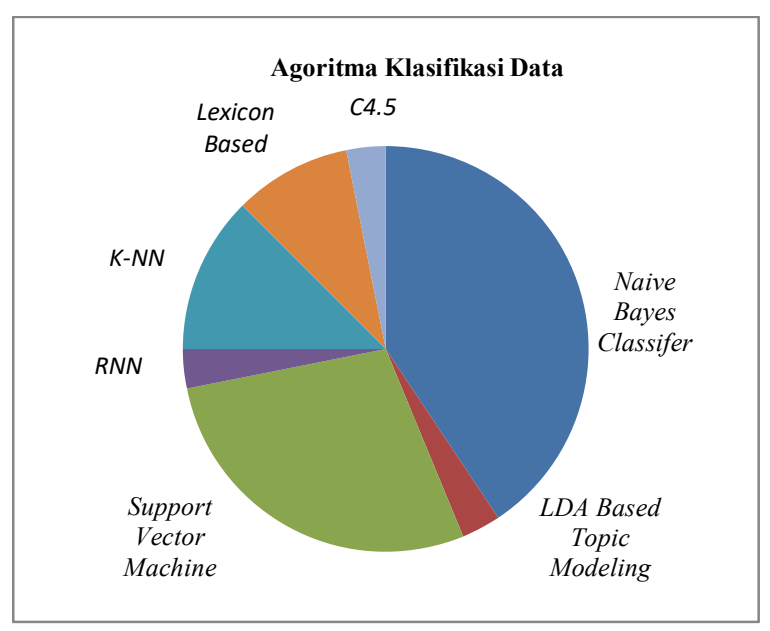

Gambar 3: Metode Klasifikasi Data

Gambar 3 merupakan jumlah dari penggunaan metode dan algoritma klasifikasi data yaitu Naive Bayes Classifier, LDA Based Topic Modeling, Support Vector Machine, RNN, K-NN, Lexicon Based dan C4.5. Berdasarkan literature yang ada algoritma yang sering digunakan dalam proses klasifikasi data adalah Naive Bayes Classifier. Menurut Andi (2018) mengatakan bahwa algoritma Naive Bayes Classifier memiliki nilai akurasi yang sangat baik daripada algoritma sebelumnya ini dikarenakan algoritma tersebut mudah digunakan, hanya membutuhkan proses satu kali iterasi data traning, dan jumlah data uji bisa dilakukan dalam jumlah kecil [34].

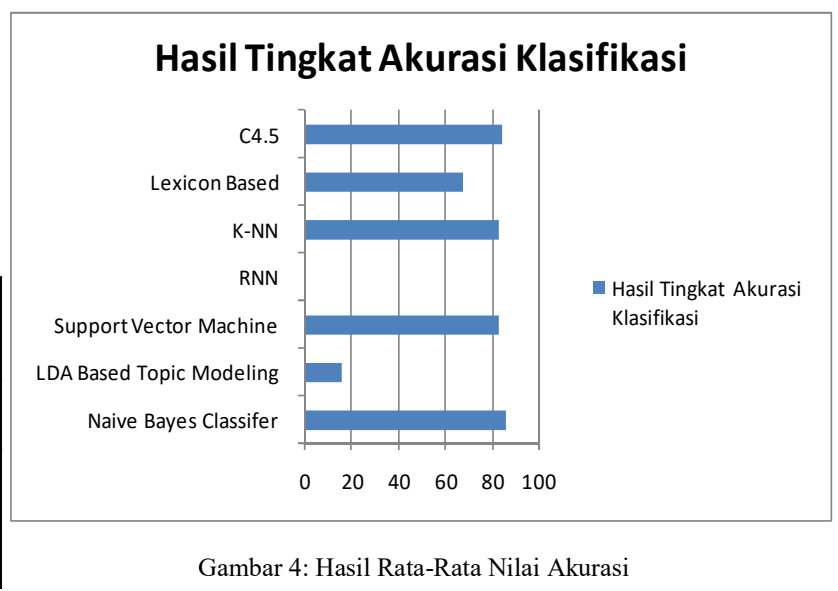

p-ISSN:1693 - 2951; e-ISSN: 2503-2372 
Gambar 4 merupakan hasil akurasi rata-rata dari algoritma yang digunakan. Algoritma Naive Bayes Classifier menghasilkan nilai akurasi rata-rata sebesar $85,08 \%$. Beberapa literatur yang sudah dibahas untuk mendapatkan nilai akurasi tinggi dipengaruhi juga pada jumlah data latih, sehingga akurasi yang dihasilkan maksimal. Menurut Mochammad Haldi mengungkapkan bahwa nilai akurasi juga dapat dipengaruhi apabila probabilitas kondisionalnya bernilai nol, maka probabilitas prediksi akan menghasilkan nilai yang sama [35]. Sehingga untuk pemakaian algoritma Naive Bayes Classifier dapat dilihat dari keperluan data apa saja yang akan diolah. Algoritma Naive Bayes sangat baik dalam analisis teks data yang banyak tidak diperkenaankan untuk tampilan gambar. Selain algoritma Naive Bayes Classifier dari review penelitian sebelumnya yang banyak digunakan adalah algoritma Support Vector Machine pemakaian algoritma tersebut dapat menghasilkan nilai akurasi yang maksimal. Seperti penelitian pada pemantauan opini masyarakat terhadap produk yang menggunakan perbandingan dengan algoritma $N B C$ dan $S V M$ hasil dari penelitian tersebut algoritma $S V M$ lebih tinggi nilai akurasi dibanding $N B C$. Ini dikarenakan data yang diambil tidak hanya berupa teks melainkan gambar emosional atau emoticon dapat dijadikan data.

\section{Rencana Penelitian}

Beberapa penelitan yang telah dilakukan dalam penerapan analisis sentimen pada media sosial. Penelitian dilakukan dengan memilih data di media sosial Twitter dan Instagram. Selain itu pengguna algoritma yang digunakan Naive Bayes Classifier untuk menghasilkan tingkat akurasi yang maksimal dan bahasa code pemrograman yang dapat dimengerti. Berdasarkan hal tersebut, maka muncul sebuah rencana penelitian dengan melakukan Analisis Sentimen Masyarakat Terhadap Perusahaan Asuransi Terbaik di Infobank 2019 Berdasarkan Opini dari Twitter dan Instagram Menggunakan Naive Bayes Classifier. Tahapan dari rencana penelitian ditunjukkan pada Gambar 5.

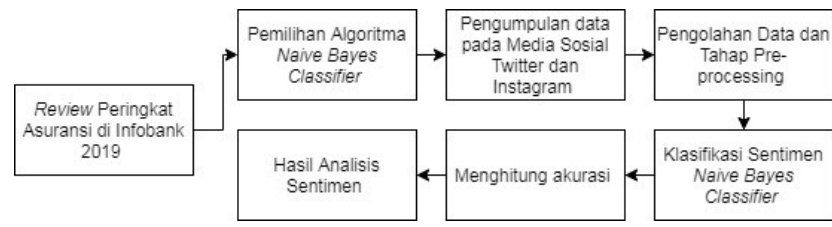

Gambar 5: Alur Rencana Penelitian

Dalam rencana penelitian ini, tahapan pertama dilakukan review peringkat asuransi di Infobank 2019, penelitian yang dilakukan hanya ke 10 asuransi di Indonesia. Selanjutnya tahapan kedua dilakukan pemilihan algoritma Naive Bayes Classifier. Pada tahapan ketiga dilakukan pengumpulan data pada Media Sosial di Twitter dan Instagram dengan menggunakan hastag ke nama 10 perusahaan asuransi. Tahapan keempat dari data yang sudah diambil di media sosial akan diolah data dan melakukan tahap pre-processing. Tahap kelima dilakukan klasifikasi sentimen melalui algoritma Naive Bayes sehingga mendapatkan kelas positif, negatif, dan netral. Tahap keenam melakukan perhitungan hasil akurasi klasifikasi data sehingga mendapatkam hasil analisis sentimen terhadap perusahaan Asuransi.

\section{KESIMPULAN}

Berdasarkan dari hasil telaah yang dilakukan, dalam melakukan analisis sentimen pada media sosial dapat dilakukan pemilihan media sosial untuk mencari opini dan data yang diperlukan sehingga mendapatkan informasi yang berguna. Selanjutnya pemilihan algoritma klasifikasi yang tepat sehingga proses perhitungan akurasi mendapatkan hasil yang maksimal.

Algoritma yang digunakan seperti Naive Bayes dan Support Vector Machine dapat meningkatkan hasil akurasi yang sangat tinggi. Dimana rata-rata literature menggunakan algoritma tersebut dengan pengambilan data di media sosial Twitter. Hasil akurasi dari masing-masing algoritma berbeda-beda, perbedaan terlihat pada pengambilan data uji disetiap penelitian.

\section{REFERENSI}

[1] Kemkominfo : Pengguna Internet di Indonesia, dari URL :https://kominfo.go.id/index.php/content/detail/3980/Kemkomin fo $\% 3$ A +Pengguna + Internet + di + Indonesia + Capai $+82+$ Juta/0/berit a_satker

[2] Afshoh, Fauziah. 2017. Analisa Sentimen menggunakan Naive Bayes untuk Melihat Persepsi Masyarakat Terhadap Kenaikan Harga Jual Rokok Pada Media Sosial Twitter. Universitas Muhamadiyah, Surakarta.

[3] Sekawanmedia (2020): Pengaruh Pengguna Media Sosial dan manfaat untuk bisnis, dari URL:https://www.sekawanmedia.co.id/mediasosial-untuk-bisnis/ [4] S. Kamran, M. Shaikh, A. Naseem, and
Kamble, P. Traffic Monitoring Using the Techniques of Data Mining," Int. J. Innov. Res. Comput. Commun

[5] Zimmerman, Jan, dan Ng, Deborah for Dummies. 2017. Social Media Marketing : All-in-One. Canada: John Wiley \& Sons.

[6] Kadek Ary B., Made Sudarma, dan Wayan G. A.” Analisis Sentimen Pada Video di Media Sosial Youtube Menggunakan STRUCTSVM'. Majalah Ilmiah Teknologi Elektro. Vol. 18.No1. Jan-April 2019. DOI: https://doi.org/10.24843/MITE.2019V1.8i01.P17.ISSN: 1693-2951.

[7] Informatikalogi.com dari URL: https://informatikalogi.com/algoritma-naive-bayes/

[8] V. Ambasador Flores, Lie Jasa, dan Linawati. "Analisis Sentimen untuk Mengetahui Kelemahan dan Kelebihan Pesaing Bisnis Rumah Makan Berdasarkan Komentar Positif dan Negatif di Instagram”. Majalah Ilmiah Teknologi Elektro. Vol 19. No 1 Jan-Jun 2020. DOI: https://doi.org/10.24843/MITE.2020.v19i01.P07

[9] Elok N.H., dan M. Balya I.A.” Pengembangan Sistem Analisis Sentimen Berbasis Java Pada Data Twitter Terhadap Omnibus Law Menggunakan Algoritma Naive Bayes dan K-Nears Neighbor (KNN) ’. JIP Vol.7. Feb 2021. ISSN: 2614-6371.

[10] I Komang Dharmendra, K. Oka Saputra, N. Pramaita. “ Analisa Sentiment Untuk Opini Alumni Pada Perguruan Tinggi” Majalah Ilmiah Teknologi Elektro, Vol.18, No. 2, Mei - Agustus 2019. DOI: https://doi.org/10.24843/MITE.2019.vl8i02.P11

[11] M. Akbar Maulana, A. Setyanto, dan M.P Kurniawan. "Analisis Sentimen Media Sosial Universitas AMIKOM Yogyakarta sebagai Sarana Penyebaran Informasi Menggunakan Algoritma Klasifikasi SVM. ISSN : 2302-3805, 2018.

[12] G. Ayu Vida Mastrika Giri “ Klasifikasi Musik Berdasarkan Genre dengan Menggunakan K-Nearest Neighbor" Jurnal Ilmu Komputer Vol. XI No2. P-ISSN: 1979-5661. E-ISSN: 2622-321X. 2018.

[13] Afshoh, Fauziah. 2017. Analisa Sentimen menggunakan Naive Bayes untuk Melihat Persepsi Masyarakat Terhadap Kenaikan Harga Jual Rokok Pada Media Sosial Twitter. Universitas Muhamadiyah, Surakarta.

[14] Nadika, Tifani. 2018 . Analisa Sentimen Menggunakan Data Twitter, Flume, Hive , Pada Hadoop dan Java untuk Deteksi Kemacetan di Jakarta.Sekolah Tinggi Ilmu Ekonomi ( STIE ), Jakarta. 
Majalah Ilmiah Teknologi Elektro, Vol. 20, No. 2, Juli-Desember 2021

DOI: https://doi.org/10.24843/MITE.2021.v20i02.P01

[15] Kabiru, Irawan Noor , dkk. 2019. Analisa Konten Media Sosial ECommerce pada Instagram Menggunakan Metode Sentimen Alysis dan LDA-BasedTopic Modeling ( Studi Kasus : Shopee Indonesia ). Universitas Telkom, Bandung.

[16] Mahardhika, Yonathan Sari, dan Zuliarso, Edri.2018. Analisis Sentimen Terhadap Pemeritahan Joko Widodo Pada Media Sosial Twitter Menggunakan AlgoritmaNaiveBayesClassifier UniveritasStikubank, Semarang

[17] Putu Sri Merta, Linawati, dan S. Komang Oka .2019. "Pengguna Metode Naïve Bayes Classifierpada Analisis Sentimen Facebook Berbahasa Indonesia. Universitas Udayana. Majalah Ilmiah Teknologi Elektro, vol. 18, no. 1, P-ISSN:1693-2951, 2019. DOI:https://doi.org/10.24843/MITE.2019.vl8i01.P22.

[18] Z. Jianqiang and G. Xiaolin, 2017. Comparison Research on Text Preprocessing Methods on Twitter Sentiment Analysis. IEEE Acess vol 5.

[19] W. Qi, R. Procter, J. Zhang and W. Guo. 2019." Mapping Consumer Sentiment Toward Wireless Services Using Geopatial Twitter Data”. IEEE Access Vol 7.

[20] P. Wang, Y.Yuan, Y. Si, G. Zhu, X Zhan, J. Wang, and R. Pan. "Classification of Proactive Personality : Text Mining Based on Weibo Text and Short-Answer Questions Text". IEEE Access vol 8.May 2020.

[21] Jaspreet. S, Gurvinder. S, and Rajinfer. S. "Optimization of Sentiment Analysis Using Machine Learning Classifiers. DOI 10.1186/s13673017-0116-3 open Access 2017.

[22] Angelina P.G, dkk. “ Analisis Sentimen Aplikasi Ruang Guru di Twitter Menggunakan Algoritma Klasifikasi” Jurnal TEKNOINFO vol.14No.2,2020. ISSN:2615-224X.

[23] Arif. R dan M. Rifqi Tsani. “Analisis Sentimen Review Media Massa Menggunakan Metode C4.5 Berbasis Forward Selection”. Smart Compt Volume 8.No2. Juni 2019. P-ISSN: 2089-676X.

[24] Ferdi A, Indriati, dan Putra P.A . "Analisis Sentimen Konten Radikal di Media Sosial Twitter Menggunakan Metode Support Vector Machine (SVM). Jurnal Pengembangan Teknologi Informasi dan Ilmu Komputer. Vol.3 No.1. Januari 2019. E-ISSN: 2548-964X

[25] Amar P. Natasuwarna. "Analisis Sentimen Keputusan Pemindahan Ibukota Negara Menggunakan Klasifikasi Naive Bayes Classifier”. Seminar Nasional Sistem Informasi dan Teknik Informatika Sensitif 2019.

[26] Arsya M.P, Imam C, dan Putra.P . "Analisis Sentimen tentang Opini Maskapai Penerbangan pada Dokumen Twitter Menggunakan Support Vector Machine (SVM) “. Jurnal Pengembangan Teknologi Informasi dan Ilmu Komputer. Vol3. No.3, Maret 2019,hlm2789-2797. E-ISSN: 2548-964X.

[27] Hidayatulah.H, Debby G.P, Wilis K. "Metode Lexicon Based dan Support Sector Machine Untuk Menganalisis Sentimen Pada Media Sosial Sebagai Rekomendasi Oleh-Oleh Favorit". Seminar Nasional Inforematika 2018. UPN"Vetaran" Yogyakarta. ISSN: 1979-2328.

[28] Rifiana Arief dan Karel Imanuel. "Analisis Sentimen Topik Viral Desa Penari Pada Media Sosial Twitter dengan Metode Lexicon Based." Jurnal Ilmiah MATRIK, Vol 21 No.3, Desember 2019. ISSN: 1411-1624. e-ISSN: 2621-8089.

[29] Prananda A, Rizal S., M. Ali F." Analisis Sentimen Tentang Opini Film Pada Dokumen Twitter Berbahasa Indonesia Menggunakan Naive Bayes dengan Perbaikan Kata Tidak Baku". Jurnal Pengembangan Teknologi Informasi dan Ilmu Komputer. Vol1. No.12. Desember 2017.hlm 1733-1741. e-ISSN: 2548-964X.

[30] Atika R., Aris M., dan Junta Z. “Analisis Sentimen Publik Pada Media Sosial Twitter Terhadap Pelaksana Pilkada Serentak Menggunakan Algoritma Support Vektor Machine”. Jurusan Teknik Informatika. Universitas Dian Nuswanto 2017. ISSN :1978-8282.

[31] Ardinne L. F., Rima D.R., dan Nia Annisa F.T. “ Analisis Sentimen Masyarakat Terhadap COVID-19 Pada Media Sosial Twitter" Vol.1x No.1 (2021) FEB 2021. ISSN Media Elektronik: 12345-XYZ

[32] Ghulam Asrofi Buntoro. " Analisis Sentimen calon Gubernur Jawa Timur 2018 dengan Metode Naive Bayes Classifier”. JIPN. Volume 4. No.1 Maret 2019. e-ISSN 2541-3724.

[33] Nur Fitriyah, Budi W., dan Di Asih I.M. “ Analisis Sentimen Gojek Pada Media Sosial Twitter dengan Klasifikasi Support Vector Machine ( SVM ). Jurnal Gaussian, Vol. 9, No. 3.2020.ISSN: 23392541

[34] Andi Krisna Dewmawan dari URL : https://www.adhikrisnadermawan.com/2018/07/27/klasifikasi-naivebayes/

Putri Agung Permatasari: Survei Tentang Analisis Sentimen...
[35] Mochammad Haldi W, Binus University dari https://binus.ac.id/bandung/2019/12/algoritma-naive-bayes/
p-ISSN:1693 - 2951; e-ISSN: 2503-2372 
\{ Halaman ini sengaja dikosongkan\} 